\title{
Skin diseases in tea collectors
}

\author{
Nursel Dilek ${ }^{1^{*}}$, Aziz Ramazan Dilek $^{2}$, Yunus Saral ${ }^{1}$, Ahmet Metin $^{1}$ \\ ${ }^{1}$ Dermatology Department of Recep Tayyip Erdoğan University, Medical Faculty Hospital, Rize, Turkey; \\ *Corresponding Author: nur.dilek@hotmail.com \\ ${ }^{2}$ Microbiology Department of Recep Tayyip Erdoğan University, Medical Faculty Hospital, Rize, Turkey
}

Received 20 November 2013; revised 21 December 2013; accepted 31 December 2013

Copyright (c) 2014 Nursel Dilek et al. This is an open access article distributed under the Creative Commons Attribution License, which permits unrestricted use, distribution, and reproduction in any medium, provided the original work is properly cited. In accordance of the Creative Commons Attribution License all Copyrights (C) 2014 are reserved for SCIRP and the owner of the intellectual property Nursel Dilek et al. All Copyright @ 2014 are guarded by law and by SCIRP as a guardian.

\section{ABSTRACT}

The tea collection is a difficult and laborious task, but few studies have analyzed risks by work activities or the work environment. To investigate the effects of work activities and work environment on tea collectors by looking from dermatological perspective, detailed dermatological examination was performed on tea collectors and clinical backgrounds of the participants were questioned and all findings were noted. The participants clinically suspected for skin, hair and nail infections have been referred to our hospital microbiology laboratory for sampling. The most common diseases in the participants were allergic contact dermatitis, irritant contact dermatitis and acute paronychia. These three diseases accounted for $59.1 \%$ of the total diseases in tea collectors. Clinical background story was unremarkable in the vast majority of participants. The current study draws attention to this business area and health problems of tea collectors. The authors think that, use of protective equipment such as masks and gloves during working and receiving of safety training related to their job will decrease work-related health problems of tea collectors.

\section{KEYWORDS}

Tea; Skin; Diseases; Collectors

\section{INTRODUCTION}

The tea (Camellia sinensis) has been cultivated in China about 2000 years ago, where its leaves were processed and its infusion used as a palatable drink [1]. Nowadays tea is the most widely consumed plant-based beverage in the world [2]. Tea is cultivated in over 30 countries/areas of the world including Bangladesh, China, Georgia, India, Indonesia, Iran, Japan, Kenya, Malawi, Malaysia, Sri Lanka, Taiwan, Tanzania, Thailand, Turkey and Uganda [1]. Turkey holds a significant place among the world's largest tea producers and is ranked as 6th among the world tea production and tea plantation has been growing in the Eastern Black Sea Region in an area of 76.632 ha [3]. While performing routine outpatient services we have noticed that some skin diseases occur more frequently in tea collectors and we decided to investigate the reason of this situation. We have examined the working environment of tea collectors and determined that tea collection is done with cutting by tea scissors and the collectors may be subjected to a number of factors originating from tea and soil such as fertilizer residue, animal feather, faeces, various insects and weeds. Although many people work in this business field there are very few studies about the effect of the tea on tea workers in manufacturing process of the tea [4]. Also there is no study in the literature about tea collectors.

To supplement this literature, we planned to investigate the effects of work activities and work environment on tea collectors who work in Eastern Black Sea Region by looking from dermatological perspective.

\section{METHOD}

Inclusion criteria for the study were formation of new skin lesions or increase in complaints after returning to work. Exclusion criteria were old skin lesions or absence of any connection of skin lesions with nature of the work. A total of 852 tea collectors (760 females, 92 males, mean age: $36.7 \pm 12.0$ years) who have complaint of skin manifestations such as itching, wound and ache were included in the study. Detailed dermatological examination was performed on all participants and clinical backgrounds of the participants were questioned and all find- 
ings were noted. The participants clinically suspected for skin, hair and nail infections have been referred to our hospital microbiology laboratory for sampling. Wound sampling was performed using cotton swabs for bacterial infections. All samples consisted of scales and scrapings taken from lesions for fungal infections. Wound samples were inoculated in blood agar and EMB agar and incubated 18 - 24 hours at $37^{\circ} \mathrm{C}$. Samples taken for examination of fungi, were examined by direct microscopy with $10 \% \mathrm{KOH}$ and Calcofluor white stain and were cultured on Sabouraud dextrose agar (SDA) (Oxoid Ltd, Basingstoke, Hampshire, England) and Mycosel agar (BBL; Becton Dickenson and Company, Cockeysville, MD, USA). Diagnoses were based on signs, symptoms, and laboratory findings. All statistical analyses were performed using SPSS software version 18.0.

\section{RESULTS}

The most common diseases in the participants were allergic contact dermatitis, irritant contact dermatitis and acute paronychia. These three diseases accounted for $59.1 \%$ of the total diseases in tea collectors. Table 1 shows the types of the disease in participants.

Clinical background story was unremarkable in the vast majority of participants. Clinical backgrounds of the participants are shown in Table 2.

In accordance with the shape of work, hands and arms have been identified as the most affected region (93.2\%). Figure 1 shows thelocalization of disease Mixed flora was isolated in significant portion of patients with acute paronychia (32.3\%). The most common infectious agent was Staphyloccocusaureus. Trichophyton rubrum was the most common of the dermatophytes causing finger-

Table 1. Frequency and prevalence of the diseases in participants.

\begin{tabular}{ccc}
\hline Diagnosis & Frequency (n) Percent (\%) \\
\hline $\begin{array}{c}\text { Allergic contact dermatitis } \\
\text { Irritant contact dermatitis }\end{array}$ & 212 & 24.9 \\
$\begin{array}{c}\text { Erosio interdigitale } \\
\text { blastomycetica }\end{array}$ & 156 & 18.3 \\
Tinea manuum & 96 & 11.3 \\
Acute paronychia & 32 & 3.8 \\
Chronic paronychia & 136 & 16.0 \\
Cellülitis & 24 & 2.8 \\
Onychomycosis + Chronicparonychia & 44 & 3.8 \\
$\begin{array}{c}\text { Allergic contact dermatitis + Erosio } \\
\text { interdigitale blastomycetica }\end{array}$ & 80 & 5.2 \\
Tinea incognito & 40 & 9.4 \\
Total & 852 & 100.0 \\
\hline
\end{tabular}

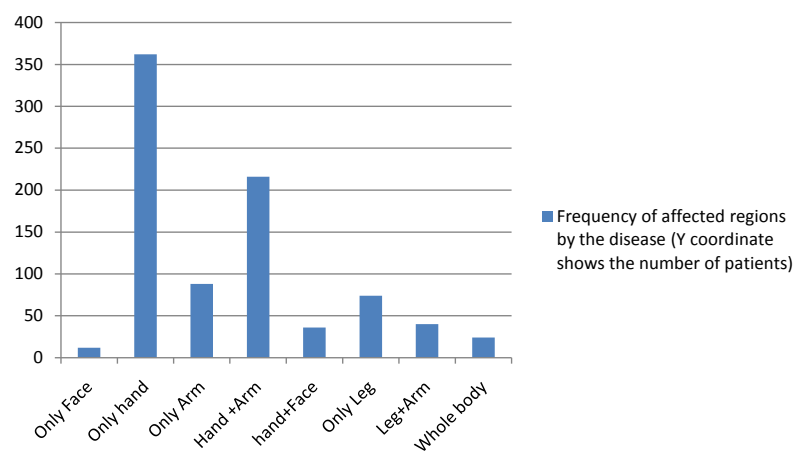

Figure 1. Frequency of affected regions by the disease.

Table 2. Frequency and prevalence of diseases in clinical backgrounds of the participants.

\begin{tabular}{ccc}
\hline Clinical backgrounds of the participants & Frequency (n) & Percent (\%) \\
\hline Unremarkable & 606 & 71.1 \\
Allergic contact dermatitis & 44 & 5.2 \\
Irritant contact dermatitis & 38 & 4.5 \\
Atopic dermatitis & 42 & 4.9 \\
Asthma & 32 & 3.8 \\
Urticaria & 40 & 4.7 \\
Rosacea & 14 & 1.6 \\
Psoriasis & 16 & 1.9 \\
Vitiligo & 20 & 2.3 \\
Total & 852 & 100.0 \\
\hline
\end{tabular}

nail fungus infections. Microsporum gypseum was the most common of the dermatophytes causingtinea manuum and onychomycosis. The other dermatophytesin order of frequency were Epidermophyton floccosum and Trichophyton interdigitale. The bacteria and fungi isolated from patient samples are shown in Table 3.

\section{DISCUSSION}

The Eastern Black Sea Region has a rich vegetation cover. The average temperature values of the hottest month and the coldest month are $\left(26.8^{\circ} \mathrm{C}\right.$ and $\left.3.3^{\circ} \mathrm{C}\right)$ in this region [5]. The average precipitation of the coastal area of this region is more than $1000 \mathrm{~mm}$ [6]. The forest flora of the region is comprised of various trees, shrubs, herbaceous and woody living covers. In terms of agricultural products, tea and hazelnut are peculiar to the region and a large variety of additional products are grown, including land, vegetable and fruit groups [5].

The tea gardens are often intertwined wooded area. The tea collectors work in this rich flora. The tea collection is difficult and laborious task and done with cutting by tea scissors. Frequently women workers collect the 
Table 3. The bacteria and fungi isolatedfrom patient.

\begin{tabular}{|c|c|c|c|}
\hline Isolated infectious agents & Paronychia (total 83 patients) & \multicolumn{2}{|c|}{ Tinea manuum + Onychomycosis (total 48 patients) } \\
\hline Staphyloccocus aureus & $45.7 \% \mathrm{n}: 38$ & \multicolumn{2}{|c|}{----} \\
\hline Pseudomonas sp. & $26.5 \% \mathrm{n}: 22$ & \multicolumn{2}{|c|}{----} \\
\hline Escherichia coli & $20.4 \% \mathrm{n}: 17$ & \multicolumn{2}{|c|}{----} \\
\hline Streptococcus pyogenes & $7.2 \% \mathrm{n}: 6$ & \multicolumn{2}{|c|}{----} \\
\hline Microsporum gypseum & --- & $43.7 \%$ & $\mathrm{n}: 21$ \\
\hline Epidermophyton floccosum & ---- & $33.3 \%$ & $\mathrm{n}: 16$ \\
\hline Trichophyton interdigitale & ---- & $22.9 \%$ & $\mathrm{n}: 11$ \\
\hline
\end{tabular}

tea in this region, therefore the number of female participants in our study was significantly higher than men. In our study allergic contact dermatitis is most common disease in the participants. Although frequently plants were reported as occupational skin allergens the incidence of allergic contact dermatitis (ACD) to plants is unknown. This fact is partially due to the difficult diagnosis of this clinical problem in the community, and even when it is suspected, the identification of the species implicated can be very difficult, and the lack of appropriate purified allergens in some cases does not make possible the confirmation $[7,8]$. Nonetheless we know that, allergic contact dermatitis is a major cause of occupational skin disease and it accounts for approximately $20 \%$ of all work-related health com plaints and occupational contact dermatitis accounts for $70 \%$ to $90 \%$ of reported cases of occupational skin disease in developed countries [7,9].

Another important finding in our study is that, bacterial and fungal infections such as paronychia, cellülitis, tineamanuum and onychomycosis were found in the majority of participants. Paronychia is defined as an inflammatory disease of the nail fold and acute paronychia is frequent following minor trauma of the nail apparatus. The primary event inparonychiais the separation of the eponychium from the nail plate followed by bacterial invasion. In the majority of cases, mixed flora is found. While Staphyloccocusaureus and Streptococci spp. are the most common aerobic bacteria, Gram-negative organisms such as Pseudomonas spp., Proteus spp. and Escherichia coli or Candida albicans yeasts may be responsible for acute paronychia [10]. The dermatological pathogenic microbes could endure in the skin through the cracks, ulcers causing skin infections [11]. Soil is considered one of the most suitable environments for microbial growth [12]. Transient animals such as birds, dogs, cats and rats leave organic residues, which may contaminate the soil with keratinaceous debris and possibly propagules of keratinophilic fungi including fungal pathogens. Therefore, soil can become a potential source of infection for human beings [13]. Presence of dermatophytes in the soil was supported by a study which done on this subject [14]. Minor skin trauma that occur during tea collection and close relationship with soil and plants, may be facilitates the development of bacterial and fungal infection in these workers. The lack of clinical background story in the most participants and affected body regions by the disease supports the association between the present clinical findings and work activities and work environment of the tea collectors. In addition, to be seen less clinical findings that use protective equipment support our findings. Limitation of our study is the lack of clinically coordinated investigation in tea and soil.

\section{CONCLUSION}

Of course this study is the first report that draws attention to this business area and health problems of the workers, but there is need for further research which will be done by other medical specialties in these workers. We think that, use of protective equipment such as masks and gloves during working and receiving of safety training related to their job will decrease work-related health problems of tea collectors.

\section{REFERENCES}

[1] Klasra, M.A., Khawar, K.M. and Aasım, M. (2007) History of tea production and marketing in Turkey. International Journal of Agriculture and Biology, 9, 523-529.

[2] Sajilata, M.G., Bajaj, P.R. and Singhal, R.S. (2008) Tea polyphenols as nutraceuticals. Comprehensive Reviews in Food Science and Food Safety, 7, 229-254. http://dx.doi.org/10.1111/j.1541-4337.2008.00043.x

[3] Özyazıc1, M.A., Özyazıcı, G. and Dengiz, O. (2011) Determination of micronutrients in tea plantations in the eastern Black Sea Region, Turkey. African Journal of Agricultural Research, 6, 5174-5180.

[4] Shieh, T.S., Chung, J.J., Wang, C.J., et al. (2012) Pulmonary function, respiratory symptoms, and dust exposures among workers engaged in early manufacturing processes 
of tea: A cohort study. BMC Public Health, 12, 121. http://dx.doi.org/10.1186/1471-2458-12-121

[5] Devec1, M. (2012) An investigation on plant species diversity in Colchic Province (Turkey). African Journal of Agricultural Research, 7, 820-843.

[6] Eris, E. and Agiralioglu, N. (2012) Homogeneity and trend analysis of hydrometeorological data of the Eastern Black Sea Region, Turkey. Journal of Water Resource and Protection, 4, 99-105.

[7] Nicholson, P.J. (2011) Occupational contact dermatitis: Known knowns and known unknowns. Clinics in Dermatology, 29, 325-330.

http://dx.doi.org/10.1016/j.clindermatol.2010.11.012

[8] Cabanillas, M., Fernández-Redondo, V. and Toribio, J. (2006) Allergic contact dermatitis to plants in a Spanish dermatology department: A 7-year review. Contact Dermatitis, 55, 84-91.

http://dx.doi.org/10.1111/j.0105-1873.2006.00888.x

[9] Kaplan, D.H., Igyártó, B.Z. and Gaspari, A.A. (2012) Early immune events in the induction of allergic contact dermatitis. Nature Reviews Immunology, 12, 114-124.

[10] Wollina, U. (2001) Acute paronychia: Comparative treatment with topical antibiotic alone or in combination with corticosteroid. Journal of the European Academy of Dermatology and Venereology, 15, 82-84.

http://dx.doi.org/10.1046/j.1468-3083.2001.00177-6.x

[11] Sheikh, H.M.A. (2010) Antimicrobial activity of certain bacteria and fungi isolated from soil mixed with human saliva against pathogenic microbes causing dermatological diseases. Saudi Journal of Biological Sciences, 17, 331-339. http://dx.doi.org/10.1016/j.sjbs.2010.06.003

[12] Cavalcanti, M.A., Oliveira, L.G., Fernandes, M.J., et al. (2006) Filamentous fungi isolated from soil in districts of the Xingó region, Braz. Acta Botanica Brasilica, 20, 831837. http://dx.doi.org/10.1590/S0102-33062006000400008

[13] Vidyasagar, G.M., Hosmani, N. and Shivkumar, D. (2005). Keratinophilic fungi isolated from hospital dust and soils of public places at Gulbarga, India. Mycopathologia, 159, 13-21. http://dx.doi.org/10.1007/s11046-004-9483-1

[14] Deshmukh, S.K., Mandeel, Q.A. and Verekar, S.A. (2008) Keratinophilic fungi from selected soils of Bahrain. Mycopathologia, 165, 143-147. http://dx.doi.org/10.1007/s11046-007-9067-y 